\title{
PENGARUH TINGKAT PENERIMAAN PENGGUNAAN TEKNOLOGI TERHADAP MINAT MASYARAKAT KOTA BANJARBARU MENGGUNAKAN TEKNOLOGI SMARTHOME
}

\author{
Marsekal Hilman Faris \\ Sekolah Tinggi Ilmu Ekonomi Pancasetia Banjarmasin \\ J1. Ahmad Yani Km. 5.5 Banjarmasin \\ alfaris.telkomakses@gmail.com
}

\begin{abstract}
At this time, the world's population really needs the Internet as one of the primary technologies used in everyday life. One of them is smarthome technology. By using the UTAUT 2 theoretical basis, this study aims to determine the aspects in the acceptance of the use of technology that have a simultaneous and partial effect on the interest of the people of Banjarmasin City in using the smarthome. Based on the results of the simultaneous and partial test of this research, it can be proven that the aspects of technology acceptance have a simultaneous and partial effect on the interest of the people of Banjarbaru City in using the smarthome. From the results of the partial test, we also find that the order of the variables that influence the research on consumer buying interest, if sorted, will get the results of the most dominant one being Social Influence, then Performance Expectancy, then Price Value, then Effort Expectancy, then Habit, followed by Hedonic Motivation, and lastly is Facilitating Conditions.
\end{abstract}

Keyword : Internet, smarthome, UTAUT 2, Banjarbaru.

\begin{abstract}
Abstrak
Pada saat ini, penduduk dunia sangat membutuhkan Internet sebagai salah satu teknologi primer yang digunakan dalam kehidupan sehari - hari. Salah satunya adalah teknologi smarthome. Dengan menggunakan landasan teori UTAUT 2, penelitian ini bertujuan mengetahui aspek - aspek dalam penerimaan penggunaan teknologi yang berpengaruh secara simultan dan parsial terhadap minat masyarakat Kota Banjarmasin dalam menggunakan smarthome. Berdasarkan hasil uji simultan dan parsial penelitian ini dapat dibuktikan bahwa aspek - aspek penerimaan teknologi berpengaruh secara simultan dan parsial terhadap minat masyarakat Kota Banjarbaru dalam menggunakan smarthome. Dari hasil uji parsial juga kita mendapatkan bahwa urutan variabel yang berpengaruh dalam penelitian minat beli konsumen ini jika diurutkan akan mendapatkan hasil dari yang paling dominan adalah Social Influence, lalu Performance Expectancy, lalu Price Value, lalu Effort Expectancy, lalu Habit, dilanjutkan dengan Hedonic Motivation, dan terakhir adalah Facilitating Conditions.
\end{abstract}

Kata Kunci : internet, smarthome, UTAUT 2, Banjarbaru. 


\section{Latar Belakang}

Internet atau interconnectionnetworking merupakan dua komputer atau lebih yang saling berhubungan membentuk jaringan komputer hingga meliputi jutaan komputer di dunia, yang saling berinteraksi dan bertukar informasi (Siregar, 2010). Perkembangan teknologi informasi yang sangat cepat mendorong peningkatan permintaan masyarakat akan layanan akses internet yang cepat, praktis, dan mudah sehingga merangsang penyediaan sarana komunikasi yang membutuhkan media akses dengan bandwidth yang besar agar kebutuhan akses internet dapat dipenuhi (Rosanto et al, 2017).

Teknologi berbasis High Speed Internet (HSI) ini sangat mendukung seluruh kegiatan dalam kehidupan sehari - hari, baik itu pekerjaan, pendidikan, atau kehidupan sosial lainnya yang sudah tidak terlepas lagi dari internet. Seiring berjalannya waktu, dengan teknologi internet masyarakat bukan hanya dapat berhubungan satu sama lain, namun kini teknologi internet sudah dapat digabungkan dengan teknologi lainnya seperti infra merah / infra red dan juga radio untuk dapat menciptakan sebuah layanan baru bagi masyarakat, yaitu smarthome.

Smarthome adalah aplikasi gabungan antara teknologi dan pelayanan yang dikhususkan pada lingkungan rumah dengan fungsi tertentu yang bertujuan meningkatkan keamanan, efisiensi dan kenyamanan penghuninya. Sistem smarthome terdiri dari perangkat monitoring, perangkat kontrol, dan perangkat otomatis yang dapat di akses menggunakangadget (Masykur et al, 2016).

Penggunaan aplikasi smarthome merupakan penunjang utama dari adanya gaya hidup smartliving, dimana efektifitas dan efisiensi dalam segala hal merupakan tujuan utama. Smartliving juga merupakan satu dari enam dimensi utama yang harus dipenuhi untuk mewujudkan program smartcity. Sehingga dapat dikatakan apabila sebuah kota ingin mencanangkan program smartcity, maka kebutuhan akan smarthome merupakan salah satu kunci utama (Rosalina et al, 2014).

Penelitian ini dilatar belakangi oleh kegemaran masyarakat Indonesia yang mulai cenderung untuk menggunakan layanan smarthome meski layanan ini bisa dibilang tidak murah. Di Kota Banjarbaru khusunya, kesadaran masyarakat akan pentingnya keamanan dan kenyamanan membuat layanan ini sudah mulai diketahui oleh masyarakat.

Kesadaran masyarakat terkait pentingnya keamanan dan kenyaman di dalam rumah didukung dengan teknologi yang mumpuni ternyata sangat menarik minat masyarakat Kalimantan Selatan, sebagaimana dapat dilihat dalam tabel berikut ini:
Tabel 1. Jumlah Perangkat Smarthome Terpasang per Witel per Bulan selama Tahun 2020 (MS2N, 2020)

\begin{tabular}{|c|c|c|c|c|c|c|c|c|}
\hline $\begin{array}{c}\text { KA } \\
\text { WAS } \\
\text { AN }\end{array}$ & $\begin{array}{c}\text { WITE } \\
\text { L }\end{array}$ & $\begin{array}{l}\mathbf{J} \\
\mathbf{A} \\
\mathbf{N}\end{array}$ & $\begin{array}{l}\mathbf{F} \\
\mathbf{E} \\
\mathbf{B}\end{array}$ & $\begin{array}{l}\mathbf{M} \\
\mathbf{A} \\
\mathbf{R}\end{array}$ & $\begin{array}{l}\mathbf{A} \\
\mathbf{P} \\
\mathbf{R}\end{array}$ & $\begin{array}{l}\text { M } \\
\mathbf{E} \\
\mathbf{I}\end{array}$ & $\begin{array}{c}\text { TO } \\
\text { TA } \\
\text { L }\end{array}$ & $\begin{array}{l}\mathbf{R} \\
\mathbf{A} \\
\mathbf{N} \\
\mathbf{K}\end{array}$ \\
\hline $\begin{array}{c}\text { DIVR } \\
\text { E } 7\end{array}$ & $\begin{array}{c}\text { PAPU } \\
\text { A } \\
\text { BARA } \\
\text { T }\end{array}$ & 0 & $\begin{array}{l}6 \\
4\end{array}$ & $\begin{array}{c}23 \\
3\end{array}$ & $\begin{array}{l}5 \\
8\end{array}$ & $\begin{array}{l}4 \\
4\end{array}$ & 399 & 1 \\
\hline $\begin{array}{l}\text { DIVR } \\
\text { E } 6\end{array}$ & $\begin{array}{c}\text { BALIK } \\
\text { PAPA } \\
\mathrm{N}\end{array}$ & $\begin{array}{l}2 \\
0\end{array}$ & $\begin{array}{l}9 \\
3\end{array}$ & 38 & $\begin{array}{l}3 \\
1\end{array}$ & $\begin{array}{l}2 \\
4\end{array}$ & 206 & 2 \\
\hline $\begin{array}{c}\text { DIVR } \\
\text { E } 6 \\
\end{array}$ & $\begin{array}{c}\text { KALSE } \\
\text { L }\end{array}$ & $\begin{array}{l}4 \\
7 \\
\end{array}$ & $\begin{array}{l}2 \\
8 \\
\end{array}$ & 35 & $\begin{array}{l}2 \\
5 \\
\end{array}$ & $\begin{array}{l}1 \\
6 \\
\end{array}$ & 151 & 3 \\
\hline $\begin{array}{c}\text { DIVR } \\
\text { E } 2 \\
\end{array}$ & JAKUT & $\begin{array}{l}1 \\
8 \\
\end{array}$ & $\begin{array}{l}2 \\
5 \\
\end{array}$ & 20 & $\begin{array}{l}3 \\
0 \\
\end{array}$ & $\begin{array}{l}2 \\
9 \\
\end{array}$ & 122 & 4 \\
\hline $\begin{array}{l}\text { DIVR } \\
\text { E } 2\end{array}$ & $\begin{array}{c}\text { TANG } \\
\text { ERAN } \\
\text { G }\end{array}$ & $\begin{array}{l}3 \\
1\end{array}$ & $\begin{array}{l}1 \\
5\end{array}$ & 16 & $\begin{array}{l}1 \\
0\end{array}$ & $\begin{array}{l}1 \\
3\end{array}$ & 85 & 5 \\
\hline $\begin{array}{c}\text { DIVR } \\
\text { E } 2 \\
\end{array}$ & $\begin{array}{c}\text { JAKSE } \\
\text { L }\end{array}$ & 6 & $\begin{array}{l}1 \\
9 \\
\end{array}$ & 13 & $\begin{array}{l}1 \\
8 \\
\end{array}$ & $\begin{array}{l}1 \\
6 \\
\end{array}$ & 72 & 6 \\
\hline $\begin{array}{c}\text { DIVR } \\
\text { E } 2 \\
\end{array}$ & $\begin{array}{c}\text { JAKTI } \\
\text { M }\end{array}$ & $\begin{array}{l}1 \\
1 \\
\end{array}$ & $\begin{array}{l}1 \\
2 \\
\end{array}$ & 20 & 8 & 9 & 60 & 7 \\
\hline $\begin{array}{c}\text { DIVR } \\
\text { E } 3 \\
\end{array}$ & $\begin{array}{l}\text { SUKA } \\
\text { BUMI }\end{array}$ & 6 & $\begin{array}{l}1 \\
2 \\
\end{array}$ & 8 & $\begin{array}{l}1 \\
4 \\
\end{array}$ & $\begin{array}{l}1 \\
5 \\
\end{array}$ & 55 & 8 \\
\hline $\begin{array}{c}\text { DIVR } \\
\text { E } 6 \\
\end{array}$ & $\begin{array}{c}\text { KALB } \\
\text { AR }\end{array}$ & 6 & $\begin{array}{l}1 \\
9 \\
\end{array}$ & 18 & 6 & 4 & 53 & 9 \\
\hline $\begin{array}{c}\text { DIVR } \\
\text { E } 1 \\
\end{array}$ & $\begin{array}{l}\text { LAMP } \\
\text { UNG }\end{array}$ & 5 & $\begin{array}{l}1 \\
4 \\
\end{array}$ & 26 & 2 & 3 & 50 & 10 \\
\hline
\end{tabular}

Dari tabel diatas yang merupakan data jumlah perangkat smarthome milik PT Telkom Indonesia, Tbk selama periode Januari sampai dengan Mei 2020, dapat dilihat bahwa Witel Kalimantan Selatan menempati posisi ke tiga dalam urutan sepuluh besar witel dengan pemasangan produk smarthome terbanyak di Indonesia pada tahun 2020. Sehingga dapat dikatakan bahwa masyarakat Kalimantan Selatan sangat tertarik dengan penggunaan teknologi smarthome ini.

Selanjutnya jika kita melihat lebih dalam lagi terhadap data penggunaan produk smarthome di Kalimantan Selatan selama periode Januari sampai dengan Mei 2020, Banjarbaru menempati urutan kedua setelah area Banjarmasin sebagaimana tabel berikut ini :

Tabel 2. Data Penggunaan Smarthome di Kalimantan Selatan berdasarkan Area (MS2N, 2020)

\begin{tabular}{|c|c|}
\hline AREA DATEL & JUMLH \\
\hline BANJARMASIN & 70 \\
\hline BANJARBARU & 52 \\
\hline TANJUNG TABALONG & 26 \\
\hline BATULICIN & 3 \\
\hline TOTAL & $\mathbf{1 5 1}$ \\
\hline
\end{tabular}

Dari kedua tabel diatas dapat disimpulkan bahwa masyarakat Kota Banjarbaru berperan cukup besar dalam angka penggunaan produk smarthome, sehingga dapat dikatakan bahwa penduduk Banjarbaru cukup tertarik dengan adanya teknologi terbaru yang dapat meningkatkan kenyamanan dan keamanan di dalam rumah. 


\section{Studi Literatur}

\section{A. Internet}

Internet (Inter-Network) adalah sebutan untuk sekumpulan jaringan komputer yang menghubungkan situs akademik, pemerintahan, komersial, organisasi, maupun perorangan. Internet menyediakan akses untuk layanan telekomnunikasi dan sumber daya informasi untuk jutaan pemakainya yang tersebar di seluruh dunia (Ramadhani, 2003).

Layanan internet meliputi komunikasi langsung (email, chat), diskusi (Usenet News, email, milis), sumber daya informasi yang terdistribusi (World Wide Web, Gopher), remote login dan lalu lintas file (Telnet, FTP), dan aneka layanan lainnya. Jaringan yang membentuk internet bekerja berdasarkan suatu set protokol standar yang digunakan untuk menghubungkan jaringan komputer dan mengalamati lalu lintas dalam jaringan (Ramadhani, 2003).

Protokol ini mengatur format data yang diijinkan, penanganan kesalahan (error handling), lalu lintas pesan, dan standar komunikasi lainnya. Protokol standar pada internet dikenal sebagai TCP/IP (Transmission Control Protocol/Internet Protocol). Protokol ini memiliki kemampuan untuk bekerja diatas segala jenis komputer, tanpa terpengaruh oleh perbedaan perangkat keras maupun sistem operasi yang digunakan (Ramadhani, 2003).

Sebuah sistem komputer yang terhubung secara langsung ke jaringan memiliki nama domain dan alamat IP (Internet Protocol) dalam bentuk numerik dengan format tertentu sebagai pengenal. Internet juga memiliki gateway ke jaringan dan layanan yang berbasis protokol lainnya (Ramadhani, 2003).

\section{B. Smart Home}

Smart home adalah sistem aplikasi yang merupakan gabungan antara teknologi dan pelayanan yang dikhususkan pada lingkungan rumah dengan fungsi tertentu yang bertujuan meningkatkan efesiensi, kenyamanan dan keamanan penghuninya. Sistem smart home terdiri dari perangkat kontrol, monitoring dan otomatisasi beberapa perangkat atau peralatan rumah yang dapat diakses melalui sebuah gadget (Masykur et al, 2016).

Sistem smart home adalah sistem yang terdiri dari beberapa komponen pendukung yang saling berinteraksi satu sama lain (Yurmama et al, 2009). Sebuah rumah dapat dikatakan sebagai smart home apabila memiliki komponen personal internal networking, intellegent control dan home auotomationseperti bagan di bawah ini:

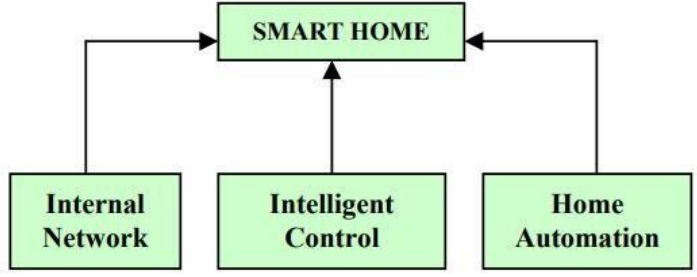

Gambar 1. Komponen Smart Home

(Yurmama et al, 2009)

Berbagai aplikasi sistem smart home dikembangkan dengan berbagai fitur sebagai konsep rumah masa depan. Aplikasi yang dibuat dibedakan dari segi fungsi dan tujuan masing-masing. Aplikasi tersebut ada yang dibuat khusus menangani satu fungsi seperti untuk sistem keamanan saja, ada pula yang merupakan gabungan dari beberapa fungsi seperti aplikasi sistem kontrol dan monitoring atau lainnya (Yurmama et al, 2009). Contoh aplikasi sistem smart home adalah seperti tabel dibawah ini:

Tabel 3. Smart Home Application

(Yurmama, et al., 2009)

\begin{tabular}{|c|c|c|c|}
\hline $\begin{array}{c}\text { Safety and } \\
\text { Security }\end{array}$ & \begin{tabular}{|c|} 
Control \\
and \\
Automatic
\end{tabular} & $\begin{array}{c}\text { Measure } \\
\text { and } \\
\text { Monitoring }\end{array}$ & $\begin{array}{l}\text { Information and } \\
\text { Communication }\end{array}$ \\
\hline $\begin{array}{c}\text { Door } \\
\text { Access } \\
\text { Control }\end{array}$ & Lighting & $\begin{array}{c}\text { Trouble / } \\
\text { Maintenanc } \\
\text { e Alert }\end{array}$ & Audio Visual \\
\hline $\begin{array}{l}\text { Sirene } \\
\text { Alarm }\end{array}$ & \begin{tabular}{|c|} 
Air \\
Conditione \\
r Control \\
\end{tabular} & $\begin{array}{c}\text { Environmen } \\
\text { t Data }\end{array}$ & Network Service \\
\hline \begin{tabular}{|c|} 
Front Door \\
/ Window \\
Observatio \\
$\mathrm{n}$
\end{tabular} & \begin{tabular}{|c|} 
Television \\
Control
\end{tabular} & $\begin{array}{l}\text { Temperatur } \\
\text { e Measure }\end{array}$ & $\begin{array}{c}\text { Telecommunicatio } \\
\text { n Service / } \\
\text { Operation }\end{array}$ \\
\hline \begin{tabular}{|c|} 
Video \\
Observatio \\
$\mathrm{n}$
\end{tabular} & \begin{tabular}{|c|} 
Automatic \\
Power \\
Switch \\
\end{tabular} & & \\
\hline
\end{tabular}

Tiga kategori smart home yaitu comfort, healthcare dan security. Comfort dan Healthcare dapat berjalan secara remote maupun secara lokal di dalam rumah. Sedang Security lebih menitikberatkan pada User Authentication dan Device Authentication (Setiawan, 2016).

1. Comfort, Salah satu fungsi utama smart home ialah mampu memberikan kenyaman yang lebih kepada penghuninya. Terdapat 2 metode yang digunakan, metode pertama, smart home akan berfungsi dengan mengenali kegiatan penghuni kemudian melakukan fungsi otomatisasi terhadap alat-alat di rumah. Metode kedua, dengan melakukan remote alat-alat rumah tangga dari jarak yang jauh (Setiawan, 2016).

2. Healthcare Smart home mampu menggantikan fungsi perawat dan asisten rumah tangga kepada pasien, orang tua, ataupun kepada orang sehat sekalipun. Fungsi healthcare dapat berupa report monitoring kesehatan penghuni yang dapat diakses oleh dokter ataupun 
monitoring keaadaan penghuni yang secara langsung terhubung ke UGD rumah sakit terdekat (Setiawan, 2016).

3. Security Rumah yang terdapat teknologi didalamnya tentu akan rentan terhadap serangan security. Permasalahan security yang paling sering terjadi dikarenakan kelemahan dari penghuni itu sendiri dan metode autentikasi yang mudah diterobos (Setiawan, 2016).

\section{Fiber to the Home (FTTH)}

Konsep FTTH merupakan suatu format transmisi sinyal optik dari pusat penyedia (provider) ke kawasan pengguna dengan menggunakan serat optik sebagai media kirimnya. Perkembangan teknologi ini tidak terlepas dari kemajuan teknologi serat optik yang menggantikan penggunaan kabel tembaga, serta munculnya layanan yang dikenal dengan istilah Triple Play Service dimana pelanggan bisa menikmati layanan data, voice, dan video semakin membuat FTTH ini diminati (Sari, 2015).

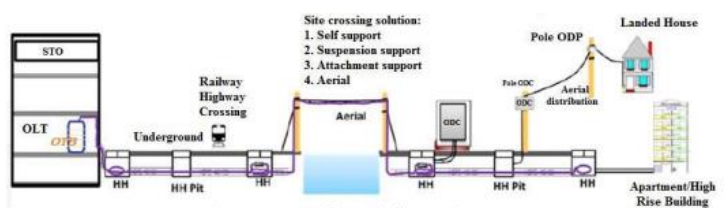

Gambar 2. Konfigurasi Fiber to The Home (Sari, 2015)

Sinyal optik dengan panjang gelombang $1490 \mathrm{~nm}$ dari hilir (downstream) dan sinyal optik dengan panjang gelombang $1310 \mathrm{~nm}$ dari hulu (upstream) digunakan untuk mengirim data, suara, dan video digital. Sedangkan untuk layanan video kabel dikonversi dahulu ke format optik dengan panjang gelombang $1550 \mathrm{~nm}$ oleh optical video transmitter. Sinyal optik $1550 \mathrm{~nm}$ dan $1490 \mathrm{~nm}$ ini digabungkan oleh coupler yang ditransmisikan ke pelanggan secara bersamaan. Jadi di FTTH terjadi pengiriman informasi yang berbeda dari tiga panjang gelombang secara simultan dan berbagai arah dalam satu kabel serat optik yang sama (Sari, 2015).

\section{Perilaku Konsumen}

Perilaku konsumen adalah tindakan yang langdung terlibat dalam mendapatkan, mengonsumsi, dan menghabiskan produk atau jasa, termasuk proses keputusan yang mendahului dan menyusuli tindakan ini (Setiadi, 2013).

Untuk memahami konsumen dan mengembangkan strategi pemasaran yang tepat kita harus memahami apa yang mereka pikirkan (kognisi) dan mereka rasakan (pengaruh), apa yang mereka lakukan (perilaku), serta di mana (kejadian di sekitar) yang mempengaruhi serta dipengaruhi oleh apa yang dipikirkan, dirasa, dan dilakukan konsumen (Setiadi, 2013).

Perilaku konsumen adalah dinamis, berarti bahwa perilaku seorang konsumen, grup konsumen, ataupun masyarakat luas selalu berubah dan bergerak sepanjang waktu. Hal ini memiliki implikasi terhadap studi perilaku konsumen, salah satu implikasinya adalah bahwa generalisasi perilaku konsumen biasanya terbatas untuk jangka waktu tertentu, produk, dan individu, atau grup tertentu (Setiadi, 2013).

Dalam pengembangan strategi pemasaran, sifat dinamis perilaku konsumen menyiratkan bahwa seseorang tidak boleh berharap bahwa suatu strategi pemasaran yang sama dapat memberikan hasil yang sama disepanjang waktu, pasar, dan industri (Setiadi, 2013).

Memahami bagaimana konsumen melakukan pengambilan keputusan akan sangat akan sangat membantu perusahaan dalam menentukan strategi pemasaran produk dan layanan yang mereka miliki (Putranto, et al., 2015). Dalam melakukan pembelian produk atau jasa biasanya konsumen mengikuti pola umum sebagai berikut : 1 . Need Recognition, 2. Information Search, 3. Evaluation of Alternative, 4. Purchase, 5. Post Purchase Behaviour (Mc Daniel, et al., 2007).

Pola diatas merupakan pola yang terjadi secara umum, namun pola tersebut tidak mutlak diikuti oleh konsumen karena mereka bisa berhenti di semua tahapan sehingga terdapat kemungkinan di mana konsumen tidak jadi melakukan pembelian. Namun dapat diperhatikan bahwa perilaku konsumen dapat dipelajari bukan hanya pada saat terjadi penjualan atau transaksi namun dimulai dari awal terjadinya kebutuhan atau keinginan konsumen, kemudian proses pencarian informasi, evaluasi, pembelian sampai dengan proses pasca pembelian (transaksi)(Putranto, et al., 2015).

\section{E. Minat Beli Konsumen}

Minat beli merupakan suatu tindakan yang dilakukan konsumen sebelum mengambil keputusan pembelian suatu produk. Minat beli merupakan tahapan ketertarikan konsumen terhadap suatu produk dan minat beli muncul setelah adanya kesadaran dan persepsi konsumen terhadap produk tertentu (Indika, 2017).

Minat beli diperoleh dari suatu proses belajar dan proses pemikiran yang membentuk suatu persepsi. Minat beli ini menciptakan suatu motivasi yang terus terekam dalam benaknya dan menjadi suatu keinginan yang sangat kuat yang pada akhirnya ketika seorang konsumen harus memenuhi kebutuhannya akan mengaktualisasikan apa yang ada didalam benaknya itu. Minat konsumen adalah 
seberapa besar kemungkinan konsumen membeli suatu merek atau seberapa besar kemungkinan konsumen untuk berpindah dari satu merek ke merek lainnya (Arista, 2011).

Minat secara bahasa adalah kecenderungan hati yang tinggi terhadap sesuatu atau gairah atau keinginan. Pengertian minat menurut istilah adalah kecenderungan atau arah keinginan terhadap sesuatu untuk memenuhi dorongan hati, dorongan dari dalam diri tersebut yang mempengaruhi gerak dan kehendak terhadap sesuatu, dan dorongan yang kuat tersebut akan mempengaruhi bagi seseorang untuk melakukan segala sesuatu dalam mewujudkan keinginan dan pencapaian tujuan dan cita-cita yang menjadi keinginan (Putranto, et al., 2015).

\section{F. Teori UTAUT 2}

UTAUT adalah singkatan dari Unified Theory of Acceptance an Use of Technology, merupakan sebuah model yang disusun berdasarkan teori dasar mengenai perilaku pengguna teknologi dan model - model adopsi atau perilaku dan penerimaan pengguna teknologi yang berkembang sebelumnya, model ini ditemukan oleh Vakantesh dan rekan - rekan pada tahun 2003 (Vakantesh, et al., 2003).

Teori - teori dan model - model tersebut antara lain : Theory of Reasoned Action (TRA), Technology Acceptance Model (TAM), Motivation Model (MM), Theory of Planned Behaviour (TPB), Combined TAM and TPB (C-TAM-TPB), Model of PC Utilization (MPCU), Innovation Diffusion Theory (IDT), dan Social Cognitive Theory (SCT). Model ini terdiri dari empat variabel sebagai faktor yang menentukan tujuan dan penggunaan teknologi informasi, yaitu: performance expectancy (ekspektasi kinerja), effort expectancy (ekspektasi usaha), social influence (pengaruh sosial) dan facilitating conditions (kondisi fasilitas), serta empat variabel sebagai moderator antara faktor penentu dengan tujuan dan penggunaan teknologi informasi, yaitu age (usia), gender (jenis kelamin), experience (pengalaman) dan volunteerism (kesukarelaan)(Vakantesh, et al., 2003).

Kemudian pada tahun 2012 Venkatesh dan rekan-rekan mengemukakan pengembangan UTAUT menjadi UTAUT2 dengan menambahkan tiga faktor penentu tujuan dan penggunaan teknologi informasi, yaitu: hedonic motivation (motivasi hedonis), price value (nilai harga) dan habit (kebiasaan) dengan fokus pada tiga variabel moderator, yaitu age (usia), gender (jenis kelamin) dan experience (pengalaman) (Vakantesh, et al., 2012). Penelitian ini menggunakan metoda UTAUT 2, karena termasuk model adposi atau perilaku dan penerimaan teknologi yang terbaru.
Gambaran dari metode UTAUT 2 adalah sebagai berikut:

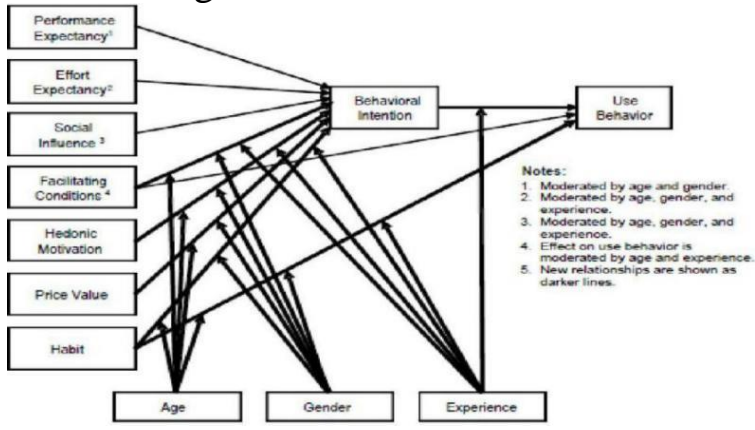

Gambar 3. Model UTAUT 2 (Vakantesh, et al., 2012)

Dalam penelitian ini, teori yang digunakan adalah The Unified Theory of Acceptance and Use of Technology (UTAUT) 2 karena berdasarkan hasil tes empiris, diketahui bahwa model UTAUT memiliki nilai variance sebesar $70 \%$ dalam menerangkan perilaku konsumen dalam kecenderungan menggunakan teknologi informasi. Sehingga UTAUT merupakan model yang memiliki daya explanatory tertinggi dibandingkan dengan delapan teori adopsi teknologi yang lainnya yang hanya memiliki $\mathrm{R}^{2}$ atau variance antara 17 - 53\% (Indrawati, 2018). Keunggulan UTAUT inilah menjadi salah satu alasan mengapa penelitian tentang teknologi smarthome ini memilih UTAUT sebagai teori acuan.

\section{Metode Penelitian}

Penelitian ini menggunakan metode kuantitatif di Kota Banjarbaru, Provinsi Kalimantan Selatan. Secara terperinci, rancangan penelitian dapat digambarkan dengan bagan berikut ini :

\begin{tabular}{|c|c|}
\hline 1. Penentuan Aspek - Aspek & $\begin{array}{c}\text { Keseluruhan aspek - aspek dalam } \\
\text { Teori UTAUT } 2\end{array}$ \\
\hline 2. Alat Pengambil Data & Mengumpulkan data hasil survey \\
\hline 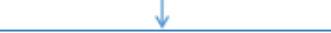 & \\
\hline 3. Penentuan Sampel & Teknik Non Probability Sampling \\
\hline \multirow[b]{2}{*}{ 4. Pengumpulan Data } & \multirow{2}{*}{$\begin{array}{l}\text { Proses survey dan pencatatan } \\
\text { hasil survey dari narasumber }\end{array}$} \\
\hline & \\
\hline 5. Analisis Data & $\begin{array}{l}\text { Melakukan analisis pada hasil } \\
\text { survey narasumber }\end{array}$ \\
\hline
\end{tabular}

Gambar 4. Rancangan Penelitian

Dari rancangan penelitian di atas, dapat dilihat bahwa penelitian ini dimulai dengan perancangan aspek - aspek apa saja yang akan diteliti. Aspek yang dijadikan acuan adalah aspek - aspek sesuai dengan Teori UTAUT 2 yakni ekspektasi kinerja, ekspektasi usaha, pengaruh sosial, kondisi fasilitas, motivasi hedonis, nilai harga, dan kebiasaan. Selanjutnya adalah alat pengambil data yang digunakan adalah melakukan survey kepada para narasumber, dengan peroses penentuan sampel yakni teknik non probability sampling.

Setelah itu dilakukan proses pengumpulan data dengan melaksanakan kegiatan survey terhadap para narasumber dan 
melakukan analisis data hasil survey dan menentukan aspek - aspek yang dimaksud dalam hipotesis.

Penelitian ini menggunakan metode survey dengan pendekatan teori UTAUT 2 sebagaimana yang telah dijelaskan pada Bab II. UTAUT adalah singkatan dari Unified Theory of Acceptance an Use of Technology, merupakan sebuah model yang disusun berdasarkan teori dasar mengenai perilaku pengguna teknologi dan model - model adopsi atau perilaku dan penerimaan pengguna teknologi yang berkembang sebelumnya, model ini ditemukan oleh Vakantesh dan rekan - rekan pada tahun 2003 (Vakantesh, et al., 2003).

Kemudian pada tahun 2012 Venkatesh dan rekan - rekan mengemukakan pengembangan UTAUT menjadi UTAUT2 dengan menambahkan tiga faktor penentu tujuan dan penggunaan teknologi informasi, yaitu: hedonic motivation (motivasi hedonis), price value (nilai harga) dan habit (kebiasaan) (Vakantesh, et al., 2012).

Tabel 4. Variabel Operasional

\begin{tabular}{|c|c|c|c|c|}
\hline $\begin{array}{c}\text { Variabe } \\
1 \\
\end{array}$ & Sub Variabel & Dimensi & Indikator & $\begin{array}{c}\text { Nomor } \\
\text { Item }\end{array}$ \\
\hline \multirow{9}{*}{$\begin{array}{c}\text { Penerim } \\
\text { aan } \\
\text { Teknolo } \\
\text { gi }(\mathrm{X})\end{array}$} & \multirow[b]{2}{*}{$\begin{array}{c}\text { Ekspektasi } \\
\text { Kinerja }\end{array}$} & \multirow[b]{2}{*}{$\begin{array}{c}\text { Manfaat } \\
\text { smarthom } \\
\text { e }\end{array}$} & $\begin{array}{c}\text { Bermanfaat } \\
\text { dalam } \\
\text { kehidupan } \\
\text { sehari - hari }\end{array}$ & 1 \\
\hline & & & \begin{tabular}{|c|} 
Manfaat \\
produk \\
merupakan \\
faktor yang \\
dipertimbang \\
kan \\
\end{tabular} & 2 \\
\hline & \multirow[b]{2}{*}{$\begin{array}{c}\text { Ekspektasi } \\
\text { Usaha }\end{array}$} & \multirow{2}{*}{$\begin{array}{l}\text { Kemudaha } \\
\mathrm{n} \\
\text { mengguna } \\
\text { kan } \\
\text { smarthom } \\
\mathrm{e}\end{array}$} & $\begin{array}{c}\text { Mudah untuk } \\
\text { digunakan }\end{array}$ & 3 \\
\hline & & & $\begin{array}{c}\text { Kemudahan } \\
\text { merupakan } \\
\text { faktor yang } \\
\text { dipertimbang } \\
\text { kan }\end{array}$ & 4 \\
\hline & \multirow{3}{*}{$\begin{array}{l}\text { Pengaruh } \\
\text { Sosial }\end{array}$} & \multirow{3}{*}{$\begin{array}{l}\text { Pengaruh } \\
\text { orang - } \\
\text { orang } \\
\text { disekitar }\end{array}$} & $\begin{array}{c}\text { Teman dan } \\
\text { keluarga } \\
\text { menggunaka } \\
\text { n smarthome }\end{array}$ & 5,7 \\
\hline & & & $\begin{array}{c}\text { Mengetahui } \\
\text { alasan teman } \\
\text { dan keluarga } \\
\text { menggunaka } \\
\text { n smarthome }\end{array}$ & 6,8 \\
\hline & & & $\begin{array}{c}\text { Ingin } \\
\text { menggunaka } \\
\text { n smarthome } \\
\text { karena teman } \\
\text { dan keluarga } \\
\text { menggunaka } \\
\text { nnya }\end{array}$ & 9 \\
\hline & \multirow[t]{2}{*}{$\begin{array}{l}\text { Kondisi } \\
\text { Fasilitas }\end{array}$} & \multirow{2}{*}{$\begin{array}{l}\text { Pengaruh } \\
\text { kondisi } \\
\text { perangkat } \\
\text { dan } \\
\text { teknologi } \\
\text { pendukun } \\
\mathrm{g}\end{array}$} & $\begin{array}{c}\text { Internet yang } \\
\text { digunakan } \\
\text { memiliki } \\
\text { kecepatan } \\
\text { tinggi }\end{array}$ & 10 \\
\hline & & & $\begin{array}{c}\text { Perangkat } \\
\text { smarthome } \\
\text { mudah } \\
\text { didapatkan }\end{array}$ & 11 \\
\hline
\end{tabular}

\begin{tabular}{|c|c|c|c|c|}
\hline & $\begin{array}{l}\text { Motivasi } \\
\text { Hedonis }\end{array}$ & $\begin{array}{c}\text { Merasa } \\
\text { senang } \\
\text { dan } \\
\text { bahagia } \\
\text { mengguna } \\
\text { kan } \\
\text { smarthom } \\
\text { e }\end{array}$ & 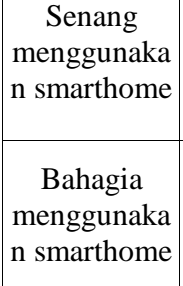 & 13 \\
\hline & \multirow{3}{*}{ Nilai Harga } & \multirow{3}{*}{$\begin{array}{c}\text { Perbandin } \\
\text { gan harga } \\
\text { dan nilai } \\
\text { guna }\end{array}$} & $\begin{array}{c}\text { Harus } \\
\text { membayar } \\
\text { untuk } \\
\text { menggunaka } \\
\text { n smarthome }\end{array}$ & 14 \\
\hline & & & $\begin{array}{c}\text { Rupian yang } \\
\text { dikeluarkan } \\
\text { sepadan } \\
\text { dengan } \\
\text { manfaat } \\
\text { smarthome }\end{array}$ & 15 \\
\hline & & & \begin{tabular}{c}
\multicolumn{1}{c}{ Akan } \\
menggunaka \\
$\mathrm{n}$ smarthome \\
jika gratis
\end{tabular} & 16 \\
\hline & \multirow[b]{2}{*}{ Kebiasaan } & \multirow{2}{*}{$\begin{array}{c}\text { Kebiasaan } \\
\text { dan } \\
\text { persepsi } \\
\text { dari } \\
\text { penggunaa } \\
\mathrm{n} \\
\text { teknologi } \\
\text { sebelumny } \\
\text { a }\end{array}$} & $\begin{array}{c}\text { Sering } \\
\text { menggunaka } \\
\text { n smarthome }\end{array}$ & 17 \\
\hline & & & $\begin{array}{c}\text { Pernah } \\
\text { menggunaka } \\
\text { n teknologi } \\
\text { sebelumnya }\end{array}$ & 18 \\
\hline $\begin{array}{c}\text { Minat } \\
\text { Masyara } \\
\text { kat }(Y)\end{array}$ & & & $\begin{array}{c}\text { Berminat } \\
\text { untuk } \\
\text { menggunaka } \\
\text { n diwaktu } \\
\text { yang akan } \\
\text { datang }\end{array}$ & 19 \\
\hline
\end{tabular}

Berdasarkan tabel variabel operasional di atas terdapat tujuh variabel yang akan diteliti dengan menggunakan teori UTAUT 2, yakni ekspektasi performa / kinerja, ekspektasi usaha, pengaruh sosial, kondisi fasilitas, motivasi hedonis, nilai harga, dan kebiasaan. Ketujuh variabel ini memiliki definisi sebagai berikut (Nugroho, et al., 2018):

1. Ekspektasi performa/kinerja didefinisikan sebagai tingkat dimana seseorang mempercayai dengan menggunakan sistem tersebut akan membantu orang tersebut untuk memperoleh keuntungankeuntungan kinerja pada pekerjaan.

2. Ekspektasi usaha merupakan tingkat kemudahan penggunaan sistem yang akan dapat mengurangi upaya (tenaga dan waktu) individu dalam melakukan pekerjaannya.

3. Pengaruh sosial didefinisikan sebagai sejauh mana seorang individual mempersepsikan kepentingan yang dipercaya oleh orang lain yang akan mempengaruhinya menggunakan sistem yang baru.

4. Kondisi yang memfasilitasi didefinisikan sebagai sejauh mana seorang percaya 
bahwa infrastruktur organisasional dan teknikal tersedia untuk mendukung sistem.

5. Motivasi hedonis adalah sejauh mana seseorang mendapat kesenangan dari teknologi yang sedang ia gunakan.

6. Nilai harga adalah persepsi seseorang terhadap biaya yang dia habiskan dalam menggunakan teknologi menuju manfaat yang dirasakannya.

7. Kebiasaan adalah sejauh mana seseorang cenderung untuk melakukan perilaku sebagai akibat dari pembelajaran.

Minat masyarakat adalah sejauh mana masyarakat menginginkan untuk menggunakan suatu produk diwaktu yang akan datang.

\section{Hasil Penelitian dan Pembahasan A. Hasil Penelitian \\ 1. Uji Validitas}

Menurut Widoyoko (2012), untuk menguji validitas instrumen atau alat ukur, dapat dilakukan dengan melakukan uji coba instrumen di lapangan. Menurut Sugiyono (2014), instrumen yang valid berarti instrumen tersebut dapat digunakan untuk mengukur apa yang seharusnya diukur. Instrumen tersebut dicobakan pada sampel dari populasi yang diambil. Setelah data ditabulasikan, maka pengujian validitas konstruksi dilakukan dengan metode Pearson Correlation, yaitu dengan cara menghitung korelasi antar skor masing-masing butir pertanyaan dengan total skor.

Menurut Widoyoko (2012), r tabel untuk $\mathrm{N}=198$ dan taraf signifikansi sebesar $5 \%$ adalah 0,138 (dibulatkan dari $\mathrm{N}=200$ ), sehingga jika hasil korelasi (r) dari setiap pertanyaan lebih dari 0,138 maka bisa dikatakan valid.

Rumus Bivariate Pearson yang digunakan adalah sebagai berikut :

$$
\mathrm{r}=\frac{N\left(\sum X Y\right)-\left(\sum X \sum Y\right)}{\sqrt{\left[N \sum^{2}-\left(\sum X\right)^{2}\right]\left[N \sum Y^{2}-\left(\sum Y\right)^{2}\right.}}
$$

Dimana :

$\begin{array}{lll}\mathrm{r} & = & \text { Koefisien Relasi } \\ \mathrm{X} & = & \text { Skor masing-masing variable } \\ \mathrm{Y} & = & \text { Skor semua total variable } \\ \mathrm{N} & = & \text { Jumlah Responden }\end{array}$

Tabel 5. Hasil Uji Validitas

\begin{tabular}{|c|c|c|}
\hline No Pertanyaan & $\mathbf{r}$ & Status \\
\hline 1 & 0,74 & Valid \\
\hline 2 & 0,61 & Valid \\
\hline 3 & 0,70 & Valid \\
\hline 4 & 0,61 & Valid \\
\hline 5 & 0,79 & Valid \\
\hline 6 & 0,78 & Valid \\
\hline 7 & 0,76 & Valid \\
\hline 8 & 0,77 & Valid \\
\hline 9 & 0,74 & Valid \\
\hline 10 & 0,77 & Valid \\
\hline 11 & 0,72 & Valid \\
\hline
\end{tabular}

\begin{tabular}{|c|c|c|}
\hline 12 & 0,80 & Valid \\
\hline 13 & 0,84 & Valid \\
\hline 14 & 0,68 & Valid \\
\hline 15 & 0,66 & Valid \\
\hline 16 & 0,41 & Valid \\
\hline 17 & 0,82 & Valid \\
\hline 18 & 0,61 & Valid \\
\hline 19 & 0,73 & Valid \\
\hline
\end{tabular}

Dari hasil uji validitas dalam tabel di atas, didapatkan bahwa semua pertanyaan dalam penelitian ini memiliki $\mathrm{r}$ lebih dari 0,138 . Sehingga semua variabel dalam penilian ini, baik itu variabel Penerimaan Teknologi (X) ataupun variabel Minat Konsumen (Y) dapat dinyatakan valid.

\section{Uji Reliabilitas}

Reliabel adalah instrumen yang bila digunakan beberapa kali untuk mengukur obyek yang sama maka akan menghasilkan data yang sama (Sugiyono, 2014).

Reliabilitas sebenarnya adalah alat untuk mengukur suatu kuesioner yang merupakan indikator dari variabel atau konstruk. Suatu kuesioner dapat dikatakan reliabel atau handal jika jawaban seseorang terhadap pertanyaan atau pernyataan adalah konsisten atau stabil dari waktu ke waktu. (Ghozali, 2013:47).

Dalam penelitian ini penulis menghitung reliabilitas dengan menggunakan teknik Koefisien Alpha Cronbach dengan rumus :

$r_{11=\frac{(k)}{(k-1)}}\left(1-\frac{\sum \sigma b^{2}}{\sigma^{2} t}\right)$

Keterangan:

r11 = reliabilitas instrumen

$\mathrm{k} \quad=$ banyaknya butir pertanyaan atau banyaknya soal

$\sum \sigma \mathrm{b} 2=$ jumlah varians butir

$\sigma^{2} \mathrm{t}=$ varians total

Dimana terdapat ketentuan dalam pengukuran reliabilitas menurut Nunnally, (1994) ; dalam Ghozali (2013:48) yaitu suatu konstruk atau variabel dapat dikatakan reliabel jika memberikan nilai Cronbach Alpha > 0,70.

Pengujian reliabilitas ini dilakukan kepada 198 responden dengan tingkat signifikansi $5 \%$ dan jumlah pertanyaan sebanyak 19 pertanyaan untuk 7 variabel. Sehingga jika dihitung dengan rumus Koefisien Alpha Cronbach didapatkan reliabilitas instrumen sebesar 0,94. Dan selanjutnya dapat ditarik kesimpulan bahwa penelitian ini memiliki nilai reliabilitas tinggi karena angka reliabilitas instrumennya lebih besar dari pada 0,70 .

\section{Uji Korelasiatau Uji Multikollinearitas}

Menurut Sarjono dan Julianita (2011), uji multikolinieritas dirancang untuk menentukan apakah ada korelasi yang tinggi 
antara keseluruhan variabel, analisis korelasi perlu dilakukan sebelum peneliti melakukan analisis regresi ataupun analisis jalur. Sebab, jika di antara variabel tidak mempunyai korelasi (tidak mempunyai hubungan) maka dapat dipastikan variabel tersebut tidak mungkin mempunyai pengaruh. Oleh karena itu, uji korelasi perlu dilakukan untuk memastikan bahwa variabel-variabel yang diteliti mempunyai hubungan. Suatu variabel yang mempunyai hubungan belum tentu mempunyai pengaruh. Namun demikian, jika suatu variabel mempunyai pengaruh terhadap variabel lain maka dapat dipastikan variabel tersebut mempunyai hubungan.

Uji korelasi dilakukan dengan menghitung korelasi antar variabel menggunakan uji korelasi Pearson Product Moment dengan rumus berikut ini :

$r_{x y}=\frac{\sum x y}{(n-1) S_{X} \cdot S_{Y}}$

Sehingga perhitungan Uji Korelasi dari hasil tabulasi jawaban responden adalah sebagai berikut :

$$
\text { rxy }=\frac{\Sigma x y}{(n-1) \text { Sx.Sy }}=\frac{35,419}{197 \times 0,47 \times 0,53}=
$$

Dengan $\mathrm{x}$ dan $\mathrm{y}$ adalah hasil tabulasi jawaban responden dikurangi dengan rata rata hasil tabulasi untuk masing - masing variabel

Kemudian, hasil uji korelasi kemudian dinterpretasikan tingkat hubungannya dengan acuan seperti pada tabel berikut:

Tabel 6. Interpretasi Koefisien Korelasi

\begin{tabular}{|c|c|}
\hline Interval Koefisien & Tingkat Hubungan \\
\hline $0,8-1,000$ & Sangat Tinggi \\
\hline $0,6-0,799$ & Tinggi \\
\hline $0,4-0,599$ & Cukup Tinggi \\
\hline $0,20-0,399$ & Rendah \\
\hline $0,00-0,199$ & Sangat Rendah \\
\hline
\end{tabular}

Berdasarkan hasil hitung koefisien korelasi pada penelitian ini, didapatkan hasil sebesar 0,704. Sehingga dapat diambil kesimpulan bahwa korelasi antara variabel Penerimaan Teknologi (X) dengan variabel Minat Beli Konsumen (Y) memiliki tingkat hubungan yang tinggi.

\section{Uji Heteroskedastisitas}

Uji Heteroskedastisitas adalah uji yang menilai apakah ada ketidaksamaan varian dari residual untuk semua pengamatan pada model regresi linear. Uji ini merupakan salah satu dari uji asumsi klasik yang harus dilakukan pada regresi linear. Apabila asumsi heteroskedastisitas tidak terpenuhi, maka model regresi dinyatakan tidak valid sebagai alat peramalan (Sugiyono, 2014).

Heteroskedastisitas adalah kebalikan dari homoskedastisitas, yaitu keadaan dimana terjadinya ketidaksamaan varian dari error untuk semua pengamatan setiap variabel bebas pada model regresi. Sebaliknya, pengertian homoskedastisitas adalah keadaan dimana adanya kesamaan varian dari error untuk semua pengamatan setiap variabel bebas pada model regresi (Sugiyono, 2014).

Uji heteroskedastisitas digunakan untuk mengetahui ada atau tidaknya penyimpangan asumsi klasik heteroskedastisitas yaitu adanya ketidaksamaan varian dari residual untuk semua pengamatan pada model regresi. Prasyarat yang harus terpenuhi dalam model regresi adalah tidak adanya gejala heteroskedastisitas. Ada beberapa metode pengujian yang bisa digunakan diantaranya yaitu Uji Park, Uji Glesjer, Melihat pola grafik 0,704 regresi, dan uji koefisien korelasi Spearman.

Dalam penelitian ini, digunakan uji heteroskedastisitas dengan Uji Glesjer dan mendapatkan hasil sebagai berikut :

Tabel 7. Hasil Uji Heteroskedastisitas

\begin{tabular}{|c|c|c|}
\hline Variabel & P-value & Hasil \\
\hline X1 & 0,076 & Tidak terjadi heteroskedastisitas \\
\hline X2 & 0,135 & Tidak terjadi heteroskedastisitas \\
\hline X3 & 0,197 & Tidak terjadi heteroskedastisitas \\
\hline X4 & 0,331 & Tidak terjadi heteroskedastisitas \\
\hline X5 & 0,334 & Tidak terjadi heteroskedastisitas \\
\hline X6 & 0,377 & Tidak terjadi heteroskedastisitas \\
\hline X7 & 0,357 & Tidak terjadi heteroskedastisitas \\
\hline
\end{tabular}

Dari hasil uji di atas, dapat dilihat bahwa keseluruhan variabel tidak terjadi heteroskedastisitas karena keseluruhan nilai probabilitasnya lebih dari taraf signifikansi $5 \%$ atau dalam desimal adalah 0,05.

\section{Uji Normalitas}

Menurut Sarjono dan Julianita (2011), Uji Normalitas adalah sebuah uji yang dilakukan dengan tujuan untuk menilai sebaran data pada sebuah kelompok data atau variabel, apakah sebaran data tersebut berdistribusi normal ataukah tidak.

Uji Normalitas berguna untuk menentukan data yang telah dikumpulkan berdistribusi normal atau diambil dari populasi normal. Metode klasik dalam pengujian normalitas suatu data tidak begitu rumit. Berdasarkan pengalaman empiris beberapa pakar statistik, data yang banyaknya lebih dari 30 angka (n > 30), maka sudah dapat diasumsikan berdistribusi normal. Biasa dikatakan sebagai sampel besar. 
Namun untuk memberikan kepastian, data yang dimiliki berdistribusi normal atau tidak, sebaiknya digunakan uji normalitas. Karena belum tentu data yang lebih dari 30 bisa dipastikan berdistribusi normal, demikian sebaliknya data yang banyaknya kurang dari 30 belum tentu tidak berdistribusi normal.

Berdasarkan hasil perhitungan, berikut adalah data hasil uji normalitas setiap variabel pada penelitian ini :

Tabel 8. Hasil Uji Normalitas

\begin{tabular}{|c|c|c|c|}
\hline Variabel & L Hitung & L Tabel & Status \\
\hline $\mathrm{X} 1$ & 0,053 & 0,063 & Terdistribusi Normal \\
\hline $\mathrm{X} 2$ & 0,058 & 0,063 & Terdistribusi Normal \\
\hline $\mathrm{X} 3$ & 0,047 & 0,063 & Terdistribusi Normal \\
\hline $\mathrm{X} 4$ & 0,036 & 0,063 & Terdistribusi Normal \\
\hline $\mathrm{X} 5$ & 0,056 & 0,063 & Terdistribusi Normal \\
\hline $\mathrm{X} 6$ & 0,061 & 0,063 & Terdistribusi Normal \\
\hline $\mathrm{X} 7$ & 0,054 & 0,063 & Terdistribusi Normal \\
\hline
\end{tabular}

Dapat dilihat dari tabel di atas, bahwa berdasarkan hasil uji normalitas, keseluruhan variabel yang mempengaruhi penerimaan teknologi terhadap minat masyarakat untuk menggunakan smarthome, adalah data yang terdistibusi normal

\section{Uji Simultan (F)}

Uji simultan (uji $F$ ) dilakukan untuk menguji signifikansi pengaruh variabel penerimaan penggunaan teknologi terhadap minat masyarakat Kota Banjarbaru dalam menggunakan smarthome. Berikut ini adalah hipotesis yang digunakan :

$H_{0}$ : Aspek-aspek penerimaan penggunaan teknologi berpengaruh secara simultan terhadap minat masyarakat Kota Banjarbaru dalam menggunakan smarthome

$H_{1}$ : Aspek-aspek penerimaan penggunaan teknologi berpengaruh secara simultan terhadap minat masyarakat Kota Banjarbaru dalam menggunakan smarthome

Dengan tingkat kesalahan sebesar 5\% atau 0,05 maka kriteria pengujian hipotesis secara simultan (uji $F$ ) adalah sebagai berikut:

$F_{\text {hitung }} \leq F_{\text {tabel }}, H_{0}$ diterima.

$F_{\text {hitung }}>F_{\text {tabel }}, H_{0}$ ditolak, $H_{1}$ diterima.

Dan berikut adalah hasil perhitungan uji simultan (F) dalam penelitian kali ini :

Tabel 9. Hasil Uji Simultan (F)

ANOVA $^{a}$

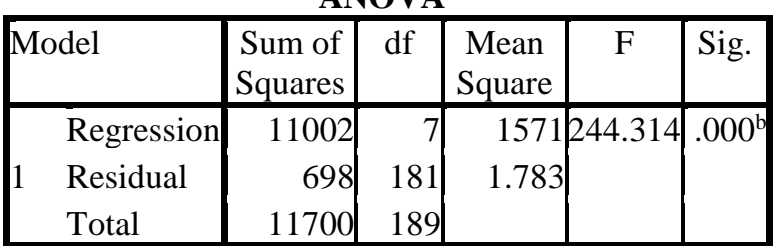

Dengan melihat tabel di atas maka didapatkan hasil $\mathrm{F}$ hitung adalah sebesar 0,76. Sedangkan nilai $\mathrm{F}$ tabel dapat dilihat pada Tabel Distribusi F dengan $\alpha=0,05$ serta $V_{1}=\mathrm{k}, V_{1}=$ jumlah variabel bebas $=7$, dan $V_{2}=\mathrm{n}-\mathrm{k}-1$, dengan $\mathrm{n}=$ jumlah sampel, $V_{2}=$ $198-7-1=190$
Dari Tabel Distribusi $F$ didapatkan nilai $F_{\text {tabel }}$ sebesar 2,05 sehingga didapatkan: $F_{\text {hitung }}(244,314)>F_{\text {tabel }}(2,05)$.

Karena $F_{\text {hitung }}$ lebih besar dari $F_{\text {tabel }}$ maka dengan mengacu pada hipotesis di atas berarti $H_{0}$ ditolak dan $H_{1}$ diterima, artinya hipotesis "Aspek-aspek penerimaan penggunaan teknologi berpengaruh secara simultan terhadap minat masyarakat Kota Banjarbaru dalam menggunakan smarthome" diterima.

\section{Uji Koefisien Determinasi}

Uji selanjutnya adalah uji Koefisien Determinasi (KD) atau uji $R^{2}$ yaitu untuk mengetahui seberapa besar pengaruh variabel dari employee engagement terhadap kinerja karyawan. Berikut ini hasil perhitungan uji KD atau uji $R^{2}$

Tabel 10. Hasil Uji Koefisien Determinasi Model Summary

\begin{tabular}{|l|r|r|r|r|}
\hline Model & \multicolumn{1}{|c|}{$\mathrm{R}$} & $\mathrm{R}$ Square & $\begin{array}{c}\text { Adjusted R } \\
\text { Square }\end{array}$ & $\begin{array}{r}\text { Std. Error of } \\
\text { the Estimate }\end{array}$ \\
\hline 1 & $.921^{\mathrm{a}}$ & .848 & .845 & 1.33516 \\
\hline
\end{tabular}

Dari Tabel 5.8 didapatkan nilai Koefisien Determinasi atau $R^{2}$ sebesar 0,848 atau $84,80 \%$ yang artinya keseluruhan variabel dalam tingkat penerimaan teknologi secara bersamaan terhadap minat masyarakat menggunakan smarthome adalah sebesar $84,80 \%$. Sedangkan sisanya sebesar $15,20 \%$ dipengaruhi oleh faktor lain yang tidak dibahas dalam penelitian ini.

\section{Uji Parsial}

Selanjutnya dilakukan penghitungan uji $t$ untuk mengetahui signifikansi dan untuk menguji secara parsial masing-masing variabel bebas yaitu kepuasan, komitmen, dan advokasi terhadap variabel terikat kinerja karyawan. Berikut ini adalah hipotesis serta kriteria pengujian:

Hipotesis:

1. Bila $H_{0}: \rho=0$, maka terdapat pengaruh tidak signifikan antara $X_{1}\left(\operatorname{atau} X_{2}\right.$, atau $\left.X_{3}\right)$ terhadap Y.

2. 2. Bila $H_{0}: \rho \neq 0$, maka terdapat pengaruh signifikan antara $X_{1}$ (atau $X_{2}$, atau $X_{3}$ ) terhadap Y.

Kriteria pengujian hipotesis:

$t_{\text {hitung }} \leq t_{\text {tabel }} ; H_{0}$ diterima.

$t_{\text {hitung }}>t_{\text {tabel }} ; H_{0}$ ditolak dan $H_{1}$ diterima

$t_{\text {hitung }}>t_{\text {tabel }} ; H_{0}$ ditolak dan $H_{1}$ diterima

Tabel 11. Hasil Uji Parsial

\begin{tabular}{|c|c|c|c|c|c|}
\hline \multicolumn{6}{|c|}{ Coefficients $^{\mathrm{a}}$} \\
\hline \multirow[t]{3}{*}{ Model } & \multicolumn{3}{|c|}{ Unstandardized Standardized } & \multirow[t]{3}{*}{$\mathrm{t}$} & \multirow[t]{3}{*}{ Sig. } \\
\hline & $\mathrm{Cos}$ & cients & Coefficients & & \\
\hline & $\mathrm{B}$ & $\begin{array}{c}\text { Std. } \\
\text { Error }\end{array}$ & Beta & & \\
\hline
\end{tabular}




\begin{tabular}{|c|c|c|c|c|c|}
\hline & (Constant) & .411 & .063 & 1.221 & .226 \\
\hline & X1 & .327 & .059 & $.305 \mid 5.528$ & .000 \\
\hline & $\mathrm{X} 2$ & .370 & .081 & .2624 .555 & .000 \\
\hline 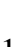 & X3 & .735 & .099 & .4387 .393 & .000 \\
\hline 1 & $\mathrm{X} 4$ & .564 & .045 & .3463 .536 & .000 \\
\hline & $\mathrm{X} 5$ & .675 & .034 & .3264 .235 & .000 \\
\hline & X6 & .786 & .056 & \begin{tabular}{|l|l|}
.375 & 5.432 \\
\end{tabular} & .000 \\
\hline & $\mathrm{X} 7$ & .356 & .035 & .2674 .347 & .000 \\
\hline
\end{tabular}

Dengan tingkat kesalahan $(\alpha)$ 5\% atau 0,05 dan $\mathrm{dk}=\mathrm{n}-\mathrm{k}=198-7=191$, dari Tabel $t$ didapatkan nilai $t_{\text {tabel }}=1,67$. Interpretasi Tabel 5.7 adalah sebagai berikut:

1. Uji $t$ dari pengaruh variabel performance expectancy (X1) terhadap minat beli konsumen masyarakat Banjarbaru untuk menggunakan smarthome.

(Y).

Berdasarkan Tabel 5.7 diketahui bahwa $t_{\text {hitung }} \mathrm{X} 1=5,528$ yang berarti $t_{\text {hitung }}$ lebih besar dari $t_{\text {tabel }}$ dan nilai signifikansi variable X1 sebesar 0,000 atau $0 \%$ yang berarti lebih kecil dari $\alpha$ yaitu 0,05 , artinya $H_{0}$ ditolak dan $H_{1}$ diterima. Hal ini menunjukan bahwa performance expectancy berpengaruh signifikan terhadap minat beli konsumen masyarakat Banjarbaru untuk menggunakan smarthome.

2. Uji $t$ dari pengaruh variabel effort expectancy (X2) terhadap minat beli konsumen masyarakat Banjarbaru untuk menggunakan smarthome. (Y). Berdasarkan Tabel 5.7 diketahui bahwa $t_{\text {hitung }} \mathrm{X} 2=4,555$ yang berarti $t_{\text {hitung }}$ lebih besar dari $t_{\text {tabel }}$ dan nilai signifikansi variable X2 sebesar 0,000 atau $0 \%$ yang berarti lebih kecil dari $\alpha$ yaitu 0,05 , artinya $H_{0}$ ditolak dan $H_{1}$ diterima. Hal ini menunjukan bahwa effort expectancy berpengaruh signifikan terhadap minat beli konsumen masyarakat Banjarbaru untuk menggunakan smarthome.

3. Uji $t$ dari pengaruh variabel social influence (X3) terhadap minat beli konsumen masyarakat Banjarbaru untuk menggunakan smarthome. (Y). Berdasarkan Tabel 5.7 diketahui bahwa $t_{\text {hitung }} \mathrm{X} 3=7,393$ yang berarti $t_{\text {hitung }}$ lebih besar dari $t_{\text {tabel }}$ dan nilai signifikansi variable X3 sebesar 0,000 atau $0 \%$ yang berarti lebih kecil dari $\alpha$ yaitu 0,05 , artinya $H_{0}$ ditolak dan $H_{1}$ diterima. Hal ini menunjukan bahwa social influence berpengaruh signifikan terhadap minat beli konsumen masyarakat Banjarbaru untuk menggunakan smarthome.

4. Uji $t$ dari pengaruh variabel facilitating conditions (X4) terhadap minat beli konsumen masyarakat Banjarbaru untuk menggunakan smarthome. (Y). Berdasarkan Tabel 5.7 diketahui bahwa $t_{\text {hitung }} \mathrm{X} 4=3,536$ yang berarti $t_{\text {hitung }}$ lebih besar dari $t_{\text {tabel }}$ dan nilai signifikansi variable $\mathrm{X} 4$ sebesar 0,000 atau $0 \%$ yang berarti lebih kecil dari $\alpha$ yaitu 0,05 , artinya $H_{0}$ ditolak dan $H_{1}$ diterima. Hal ini menunjukan bahwa facilitating conditions berpengaruh signifikan terhadap minat beli konsumen masyarakat Banjarbaru untuk menggunakan smarthome.

5. Uji $t$ dari pengaruh variabel hedonic motivation (X5) terhadap minat beli konsumen masyarakat Banjarbaru untuk menggunakan smarthome. (Y). Berdasarkan Tabel 5.7 diketahui bahwa $t_{\text {hitung }} \mathrm{X} 5=4,235$ yang berarti $t_{\text {hitung }}$ lebih besar dari $t_{\text {tabel }}$ dan nilai signifikansi variable X5 sebesar 0,000 atau $0 \%$ yang berarti lebih kecil dari $\alpha$ yaitu 0,05 , artinya $H_{0}$ ditolak dan $H_{1}$ diterima. Hal ini menunjukan bahwa hedonic motivation berpengaruh signifikan terhadap minat beli konsumen masyarakat Banjarbaru untuk menggunakan smarthome.

6. Uji $t$ dari pengaruh variabel price value (X6) terhadap minat beli konsumen masyarakat Banjarbaru untuk menggunakan smarthome. (Y). Berdasarkan Tabel 5.7 diketahui bahwa $t_{\text {hitung }}$ X6 $=5,432$ yang berarti $t_{\text {hitung }}$ lebih besar dari $t_{\text {tabel }}$ dan nilai signifikansi variable X6 sebesar 0,000 atau $0 \%$ yang berarti lebih kecil dari $\alpha$ yaitu 0,05 , artinya $H_{0}$ ditolak dan $H_{1}$ diterima. Hal ini menunjukan bahwa price value berpengaruh signifikan terhadap minat beli konsumen masyarakat Banjarbaru untuk menggunakan smarthome.

7. Uji $t$ dari pengaruh variabel habit (X7) terhadap minat beli konsumen masyarakat Banjarbaru untuk menggunakan smarthome. (Y). Berdasarkan Tabel 5.7 diketahui bahwa $t_{\text {hitung }} \times 7=4,347$ yang berarti $t_{\text {hitung }}$ lebih besar dari $t_{\text {tabel }}$ dan nilai signifikansi variable X7 sebesar 0,000 atau $0 \%$ yang berarti lebih kecil dari $\alpha$ yaitu 0,05 , artinya $H_{0}$ ditolak dan $H_{1}$ diterima. Hal ini menunjukan bahwa habit berpengaruh signifikan terhadap minat beli konsumen masyarakat Banjarbaru untuk menggunakan smarthome.

Selanjutnya setelah melakukan uji instrumen dan uji asumsi klasik, maka dapat diketahui bahwa ketujuh variabel sangat berpengaruh secara signifikan terhadap minat beli konsumen masyarakat Banjarbaru untuk menggunakan teknologi smarthome. Oleh sebab itu model penelitian ini dapat digambarkan sebagai berikut : 


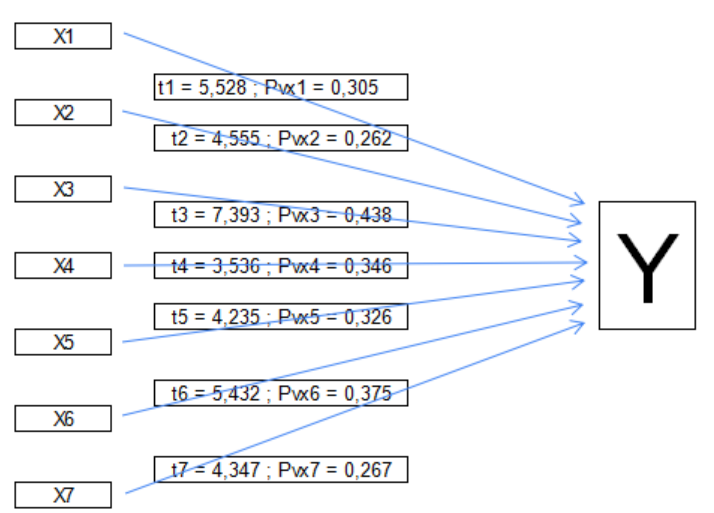

Gambar 5. Model Pengaruh Tingkat Penerimaan Teknologi (X) terhadap Minat Beli Konsumen (Y)

Sedangkan untuk korelasi antar koefisien yang lebih detail dapat dilihat pada tabel di bawah ini :

Tabel 12. Korelasi Antar Variabel

\begin{tabular}{|c|c|c|c|c|c|c|c|}
\hline & $Z X 1$ & $Z X 2$ & $Z X 3$ & ZX4 & ZX5 & ZX6 & $\begin{array}{c}Z X \\
7\end{array}$ \\
\hline $\mathrm{ZX} 1$ & 1 & & & & & & \\
\hline $\mathrm{ZX} 2$ & $\begin{array}{c}0,78746 \\
9\end{array}$ & 1 & & & & & \\
\hline $\mathrm{ZX} 3$ & $\begin{array}{c}0,63510 \\
5\end{array}$ & \begin{tabular}{|c|}
0,64917 \\
5 \\
\end{tabular} & 1 & & & & \\
\hline $\mathrm{ZX} 4$ & $\mid \begin{array}{c}0,61673 \\
1\end{array}$ & \begin{tabular}{|c|}
0,59621 \\
8 \\
\end{tabular} & $\begin{array}{c}0,76029 \\
8\end{array}$ & 1 & & & \\
\hline ZX5 & $\begin{array}{c}0,70671 \\
5\end{array}$ & 0,69732 & \begin{tabular}{|c|}
0,74006 \\
3
\end{tabular} & \begin{tabular}{|c}
0,77881 \\
8 \\
\end{tabular} & 1 & & \\
\hline ZX6 & $\begin{array}{c}0,56350 \\
1\end{array}$ & \begin{tabular}{|c|}
0,62661 \\
6 \\
\end{tabular} & \begin{tabular}{|c}
0,66486 \\
5
\end{tabular} & $\begin{array}{c}0,61130 \\
5\end{array}$ & \begin{tabular}{|c}
0,59681 \\
8 \\
\end{tabular} & 1 & \\
\hline & 0,66178 & 0,61493 & 0,76726 & 0,75403 & $\begin{array}{c}0,73013 \\
3\end{array}$ & $\begin{array}{c}0,68588 \\
1\end{array}$ & 1 \\
\hline
\end{tabular}

\section{Hasil Uji Hipotesis}

Berdasarkan semua hasil pengujian yang telah dibahas sebelumnya, maka ringkasannya disajikan dalam tabulasi berikut ini:

Tabel 13. Ringkasan Uji Hasil Hipotesis

\begin{tabular}{|c|c|c|c|c|}
\hline $\begin{array}{l}\mathbf{N} \\
\mathbf{0}\end{array}$ & Hipotesis & Nilai & $\underset{\mathbf{n}}{\text { Kesimpula }}$ & Makna \\
\hline 1 & $\begin{array}{c}\text { Aspek-aspek } \\
\text { penerimaan } \\
\text { penggunaan } \\
\text { teknologi } \\
\text { berpengaruh } \\
\text { secara } \\
\text { simultan } \\
\text { terhadap } \\
\text { minat } \\
\text { masyarakat } \\
\text { Kota } \\
\text { Banjarbaru } \\
\text { dalam } \\
\text { menggunaka } \\
\text { n } \\
\text { smarthome. }\end{array}$ & $\begin{array}{c}F_{\text {hitung }} \\
(244,314 \\
)>F_{\text {tabel }} \\
(2,05)\end{array}$ & H1 diterima & $\begin{array}{c}\text { Semakin } \\
\text { tinggi } \\
\text { pengaruh } \\
\text { keseluruhan } \\
\text { aspek - } \\
\text { aspek dalam } \\
\text { Teori } \\
\text { UTAUT 2, } \\
\text { semakin } \\
\text { tinggi juga } \\
\text { minat } \\
\text { masyarakat } \\
\text { untuk } \\
\text { menggunaka } \\
\text { n produk } \\
\text { smarthome. }\end{array}$ \\
\hline 2 & $\begin{array}{c}\text { Aspek-aspek } \\
\text { penerimaan } \\
\text { penggunaan } \\
\text { teknologi } \\
\text { berpengaruh } \\
\text { secara } \\
\text { parsial } \\
\text { terhadap } \\
\text { minat } \\
\text { masyarakat } \\
\text { Kota } \\
\text { Banjarbaru } \\
\text { dalam } \\
\text { menggunaka } \\
\text { n smarthome }\end{array}$ & $\begin{array}{c}t_{\text {hitung }} \\
\mathrm{X} 1= \\
5,528> \\
t_{\text {tabel }}= \\
1,67 \\
t_{\text {hitung }} \\
\mathrm{X} 2= \\
4,555> \\
t_{\text {tabel }}= \\
1,67 \\
t_{\text {hitung }} \\
\mathrm{X} 3= \\
7,393> \\
t_{\text {tabel }}= \\
1,67 \\
t_{\text {hitung }} \\
\mathrm{X} 4= \\
3,536> \\
t_{\text {tabel }}= \\
1,67 \\
t_{\text {hitung }}\end{array}$ & $\mathrm{H} 2$ diterima & $\begin{array}{c}\text { Semakin } \\
\text { tinggi } \\
\text { pengaruh } \\
\text { keseluruhan } \\
\text { aspek - } \\
\text { aspek dalam } \\
\text { Teori } \\
\text { UTAUT 2, } \\
\text { semakin } \\
\text { tinggi juga } \\
\text { minat } \\
\text { masyarakat } \\
\text { untuk } \\
\text { menggunaka } \\
\text { n produk } \\
\text { smarthome. }\end{array}$ \\
\hline
\end{tabular}

\begin{tabular}{|c|c|c|c|c|}
\hline & & $\begin{array}{c}\mathrm{X} 5= \\
4,235> \\
t_{\text {tabel }}= \\
1,67 \\
t_{\text {hitung }} \\
\mathrm{X} 6= \\
5,432> \\
t_{\text {tabel }}= \\
1,67 \\
t_{\text {hitung }} \\
\mathrm{X} 7= \\
4,347> \\
t_{\text {tabel }}= \\
1,67\end{array}$ & & \\
\hline 3 & $\begin{array}{c}\text { Aspek-aspek } \\
\text { penerimaan } \\
\text { penggunaan } \\
\text { teknologi } \\
\text { yang } \\
\text { berpengaruh } \\
\text { dominan } \\
\text { terhadap } \\
\text { minat } \\
\text { masyarakat } \\
\text { Kota } \\
\text { Banjarbaru } \\
\text { dalam } \\
\text { menggunaka } \\
\text { n smarthome } \\
\text { adalah aspek } \\
\text { pengaruh } \\
\text { sosial }\end{array}$ & $\begin{array}{c}t_{\text {hitung }} \\
\text { X1= } \\
5,528> \\
t_{\text {tabel }}= \\
1,67 \\
t_{\text {hitung }} \\
X 2= \\
4,555> \\
t_{\text {tabel }}= \\
1,67 \\
t_{\text {hitung }} \\
\text { X3= } \\
7,393> \\
t_{\text {tabel }}= \\
1,67 \\
t_{\text {hitung }} \\
X 4= \\
3,536> \\
t_{\text {tabel }}= \\
1,67 \\
t_{\text {hitung }} \\
X 5= \\
4,235> \\
t_{\text {tabel }}= \\
1,67 \\
t_{\text {hitung }} \\
X 6= \\
5,432> \\
t_{\text {tabel }}= \\
1,67 \\
t_{\text {hitung }} \\
X 7= \\
4,347> \\
t_{\text {tabel }}= \\
1,67\end{array}$ & $\mathrm{H} 3$ diterima & $\begin{array}{c}\text { Berdasarkan } \\
\text { hasil uji } \\
\text { parsial dari } \\
\text { aspek - } \\
\text { aspek } \\
\text { penerimaan } \\
\text { teknologi, } \\
\text { didapatkan } \\
\text { hasil bahwa } \\
\text { aspek yang } \\
\text { paling } \\
\text { dominan } \\
\text { adalah } \\
\text { pengaruh } \\
\text { sosial. Bisa } \\
\text { diartikan } \\
\text { semakin } \\
\text { tinggi } \\
\text { pengaruh } \\
\text { dari keluarga } \\
\text { dan teman } \\
\text { untuk } \\
\text { menggunaka } \\
\text { n } \\
\text { smarthome, } \\
\text { semakin } \\
\text { tinggi juga } \\
\text { minat } \\
\text { masyarakat } \\
\text { untuk } \\
\text { menggunaka } \\
\text { n smarthome }\end{array}$ \\
\hline
\end{tabular}

\section{B. Pembahasan}

Dalam Bab sebelumnya telah disebutkan bahwa tujuan dari penelitian ini adalah mengetahui aspek - aspek dalam penerimaan penggunaan teknologi yang berpengaruh secara simultan dan parsial terhadap minat masyarakat Kota Banjarmasin dalam menggunakan smarthome. Juga mengetahui aspek manakah dalam penerimaan penggunaan teknologi yang paling berpengaruh dominan terhadap minat masyarakat Kota Banjarbaru dalam menggunakan smarthome.

Jika dilihat dari karakteristik para responden, penelitian ini didominasi oleh responden laki - laki sebanyak 67\%, usia 25 35 tahun sebanyak $54 \%$, pendidikan terakhir setara D4 / S1 sebanyak 46\%, sertaposisi dalam keluarga yang didominasi oleh posisi anak sebanyak 48\%. Hal ini sangat menggambarkan bahwa masyarakat yang mendominasi ketertarikan terhadap smarthome adalah masyarakat yang berjenis kelamin laki - laki dan berumur sekitar 25 - 35 tahun, dan memiliki pendidikan terakhir setara S1. Dan fenomena yang cukup menarik adalah dimana posisi dalam keluarga yang justru tertarik dengan smarthome ini adalah posisi anak dimana bisa membuktikan bahwa 
pada zaman milenial ini, seorang anak dapat menentukan tingkatan teknologi yang digunakan didalam keluarga.

Jika dilihat dari analisis deskriptif berdasarkan persepsi responden, variabel Performance Expactancy atau Fungsi Manfaat memiliki skor paling tinggi yakni $88,01 \%$, yang selanjutnya diikuti oleh Effort Expectancy atau Fungsi Kemudahan dengan skor $85,73 \%$, lalu selanjutnya adalah variabel Hedonic Motivation dengan skor 84,66\%, lalu variabel Price Value atau Nilai Harga dengan skor $82,24 \%$, dilanjutkan dengan variabel Facilitating Conditions atau Kondisi Fasilitas dengan skor $82,13 \%$, lalu varibael Habit atau Kebiasaan dengan skor $81,5 \%$, dan yang paling kecil skornya adalah variabel Social Influence dengan skor $77,3 \%$.

Sehingga dari hasil analisis deskriptif dapat kita dapatkan makna bahwa keseluruhan aspek - aspek dalam Teori UTAUT 2 sangat berpengaruh terhadap minat masyarakat dalam menggunakan produk smarthome. Sehingga, semakin besar pengaruh dari keseluruhan aspek dalam Teori UTAUT 2, semakin besar juga minat masyarakat dalam menggunakan teknologi smarthome.

\section{Hasil Uji Simultan}

Pada hasil uji instrumen yang dibagi menjadi hasil uji validitas dan relabilitas dalam penelitian ini memiliki hasil yang sangat baik yakni penelitian ini valid dan reliabel.

Pada hasil uji asumsi klasik, penelitian ini memiliki skor korelasi yang tinggi antara variabel bebas yakni tingkat penerimaan teknologi dengan variabel terikat nya yaitu minat beli konsumen masyarakat Banjarbaru terhadap produk smarthome, dimana ini membuktikan bahwa variabel tingkat penerimaan teknologi sangat berpengaruh pada minat beli konsumen, yang sesuai juga dengan hasil uji simultan dimana penelitian ini dapat dibuktikan bahwa aspek - aspek penerimaan teknologi berpengaruh secara simultan terhadap minat masyarakat Kota Banjarbaru dalam menggunakan smarthome.

Maka dari hasil uji simultan, bisa kita dapatkan hasil bahwa keseluruhan aspek dalam Teori UTAUT 2 secara bersama - sama sangat berpengaruh terhadap minat masyarakat dalam menggunakan teknologi smarthome. Hasil uji simultan ini selaras dengan hasil uji analisis deskriptif, dimana keseluruhan aspek juga sangat berpengaruh dalam minat konsumen menggunakan smarthome.

Apek - aspek tersebut ternyata berpengaruh sebesar $84,80 \%$ terhadap minat beli konsumen sesuai dengan hasil perhitungan koefisien determinasi, dan juga didukung oleh hasil uji parsial dalam penelitian ini dimana keseluruhan aspek aspek penerimaan penggunaan teknologi berpengaruh secara parsial terhadap minat masyarakat Kota Banjarbaru dalam menggunakan smarthome.

\section{Hasil Uji Parsial}

Dari hasil uji parsial juga kita mendapatkan bahwa urutan variabel yang berpengaruh dalam penelitian minat beli konsumen ini jika diurutkan akan mendapatkan hasil dari yang paling dominan adalah X3 yakni Social Influence, lalu X1 yakni Performance Expectancy, lalu X6 yakni Price Value, lalu X2 yakni Effort Expectancy, lalu X7 yakni Habit, dilanjutkan dengan X5 yaitu Hedonic Motivation, dan terakhir adalah X4 yaitu Facilitating Conditions.

\section{Aspek Paling Dominan}

Aspek pengaruh sosial mendapatkan hasil $t_{\text {hitung }}$ sebesar 7,393 lebih besar dari pada $t_{\text {tabel }}$ yakni 1,67. Dari hasil uji parsial ini didapatkan hasil bahwa aspek pengaruh sosial memiliki pengaruh paling besar kepada minat konsumen dalam menggunakan smarthome. Sehingga didapatkan makna bahwa semakin besar pengaruh dari teman atau keluarga dalam menggunakan smarthome, semakin tinggi juga minat masyarakat dalam menggunakan teknologi ini.

Setelah aspek pengaruh sosial, aspek yang memiliki urutan kedua dalam pengaruhnya terhadap minat masyarakat dalam menggunakan smarthome adalah aspek Performance Expectancy atau Ekspektasi Kinerja, dimana aspek ini adalah aspek yang dipertimbangkan oleh masyarakat dalam sisi manfaatnya dalam kehidupan sehari - hari, dan apakah teknologi ini membantu efektifitas kegiatan dalam mengawasi dan mengontrol rumah. Aspek ini mendapatkan nilai $t_{\text {hitung }}$ sebesar 5,528 lebih besar dari pada $t_{\text {tabel }}$ yakni 1,67. Sehingga didapatkan makna bahwa semakin besar manfaat smarthome dalam kehidupan sehari - hari, semakin besar juga minat konsumen dalam menggunakan smarthome.

Selanjutnya setelah Performance Expectancy, urutan ketiga ditempati oleh aspek Price Value atau Nilai Harga, yakni seberapa besar manfaat smarthome jika dibandingkan dengan nilai rupiah yang harus dikeluarkan. Nilai harga juga ternyata sangat berpengaruh dengan nilai $t_{\text {hitung }}$ sebesar 5,432 lebih besar daripada $t_{\text {tabel }}$ yakni 1,67. Sehingga didapatkan makna bahwa semakin besar nilai manfaat dibandingkan dengan nilai rupiah yang harus dikeluarkan, maka semakin besar juga minat masyarakat dalam menggunakan teknologi smarthome.

Selanjutnya pada urutan keempat ditempati oleh aspek Effort Expectancy atau 
Ekspektasi Usaha, dimana aspek ini adalah aspek seberapa mudah teknologi smarthome ini dapat digunakan oleh berbagai kalangan masyarakat. Aspek ini juga cukup berpengaruh dengan hasil $t_{\text {hitung }}$ sebesar 4,555 lebih besar daripada $t_{\text {tabel }}$ yakni 1,67. Sehingga didapatkan makna bahwa semakin mudah teknologi ini digunakan, semakin besar minat masyarakat dalam menggunakan teknologi smarthome.

Setelah aspek Ekspektasi Usaha, urutan kelima ditempati oleh aspek Habit atau kebiasaan. Sebagaimana kita tahu, bahwa masyarakat sudah cukup familiar dengan teknologi terdahulu dari smarthome yaitu teknologi CCTV yang sudah dipasang hampir di semua lokasi, juga sensor - sensor lainnya yang sudah cukup dikenal oleh masyarakat. Seluruh teknologi terdahulu yang sudah familiar dibenak masyarakat, membuat aspek Kebiasaan juga menjadi salah satu aspek yang berpengaruh dalam minat masyarakat dalam menggunakan smarthome, dapat dilihat juga dari nilai $t_{\text {hitung }}$ sebesar 4,347 lebih besar daripada $t_{\text {tabel }}$ yakni 1,67. Sehingga didapatkan makna bahwa semakin besar seseorang terbiasa dengan teknologi terdahulu seperti CCTV dan sensor lainnya, semakin besar juga minatnya dalam menggunakan teknologi smarthome.

Setelah aspek Kebiasaan, urutan keenap ditempati oleh aspek Hedonic Motivation atau Motivasi Hedonis, dimana seseorang merasa senang dan bahagia dalam menggunakan smarthome. Ternyata aspek ini tidak sebesar pengaruh dari aspek lain, ditunjukkan dengan nilai $t_{\text {hitung }}$ sebesar 4,235 yang masih lebih besar daripada $t_{\text {tabel }}$ yakni 1,67. Meskipun tidak seberpengaruh aspek yang lain, namun dari nilai uji parsial didapatkan makna bahwa semakin besar seseorang memperoleh kesangan dan kebahagiaan dalam menggunakan smarthome, semakin besar juga minatnya dalam menggunakan teknologi ini.

Pada urutan terakhir dari uji parsial ini, didapatkan aspek Facilitating Condition atau Kondisi Fasilitas dari teknologi smarthome. Meskipun menempati posisi paling terakhir dari semua aspek yang dipertimbangkan sebelum memakai teknologi smarthome, aspek ini ternyata masih saja berpengaruh dengan nilai $t_{\text {hitung }}$ sebesar 3,536 lebih besar daripada $t_{\text {tabel }}$ yakni 1,67. Sehingga didapatkan makna bahwa semakin besar kondisi perangkat dan fasilitas lainnya mendukung dalam penggunaan smarthome, maka semakin besar juga minat masyarakat dalam menggunakan teknologi ini.

Sehingga dapat disimpulkan bahwa Hipotesis Pertama, Kedua dan Ketiga diterima. Bahwa seluruh aspek dalam Teori UTAUT 2 berpengaruh secara simultan dan parsial terhadap minat masyarakat dalam menggunakan teknologi smarthome. Dan aspek yang berpengaruh paling dominan adalah aspek Social Influence atau Pengaruh Sosial.

\section{Kesimpulan}

Berdasarkan keseluruhan hasil dalam penelitian pengaruh tingkat penerimaan teknologi terhadap minat beli konsumen masyarakat Banjarbaru dalam menggunakan smarthome, didapatkan kesimpulan sebagai berikut :

1. Berdasarkan hasil dari karakteristik para responden, penelitian ini didominasi oleh responden laki - laki sebanyak $67 \%$, usia 25 - 35 tahun sebanyak 54\%, pendidikan terakhir setara D4 / S1 sebanyak 46\%, serta posisi dalam keluarga yang didominasi oleh posisi anak sebanyak 48\%. Berdasarkan hasil dari analisis deskriptif berdasarkan persepsi responden, variabel Performance Expactancy atau Fungsi Manfaat memiliki skor paling tinggi yakni $88,01 \%$, yang selanjutnya diikuti oleh Effort Expectancy atau Fungsi Kemudahan dengan skor $85,73 \%$, lalu selanjutnya adalah variabel Hedonic Motivation dengan skor 84,66\%, lalu variabel Price Value atau Nilai Harga dengan skor $82,24 \%$, dilanjutkan dengan variabel Facilitating Conditions atau Kondisi Fasilitas dengan skor 82,13\%, lalu varibael Habit atau Kebiasaan dengan skor $81,5 \%$, dan yang paling kecil skornya adalah variabel Social Influence dengan skor 77,3\%. Berdasarkan hasil uji validitas dan relabilitas dalam penelitian ini memiliki hasil yang sangat baik yakni penelitian ini valid dan reliabel. Keseluruhan variabel dalam penelitian ini memiliki skor uji validitas lebih dari 0,138 dan memiliki skor uji reliabitilas sebesar 0,94. Berdasarkan hasil uji asumsi klasik, penelitian ini memiliki skor korelasi yang tinggi antara variabel bebas yakni tingkat penerimaan teknologi dengan variabel terikat nya yaitu minat beli konsumen masyarakat Banjarbaru terhadap produk smarthome

2. Berdasarkan hasil uji simultan dimana penelitian ini dapat dibuktikan bahwa aspek - aspek penerimaan teknologi berpengaruh secara simultan terhadap minat masyarakat Kota Banjarbaru dalam menggunakan smarthome. Berdasarkan hasil uji koefisien determinasi, variabel variabel dalam penelitian ini berpengaruh sebesar $84,80 \%$ terhadap minat beli konsumen . Berdasarkan hasil uji parsial dalam penelitian ini, keseluruhan aspek - aspek penerimaan penggunaan teknologi 
berpengaruh secara parsial terhadap minat masyarakat Kota Banjarbaru dalam menggunakan smarthome. Dari hasil uji parsial juga kita mendapatkan bahwa urutan variabel yang berpengaruh dalam penelitian minat beli konsumen ini jika diurutkan akan mendapatkan hasil dari yang paling dominan adalah X3 yakni Social Influence, lalu X1 yakni Performance Expectancy, lalu X6 yakni Price Value, lalu X2 yakni Effort Expectancy, lalu X7 yakni Habit, dilanjutkan dengan X5 yaitu Hedonic Motivation, dan terakhir adalah $\mathrm{X} 4$ yaitu Facilitating Conditions.

3. Hipotesis Pertama, Kedua dan Ketiga diterima. Bahwa seluruh aspek dalam Teori UTAUT 2 berpengaruh secara simultan dan parsial terhadap minat masyarakat dalam menggunakan teknologi smarthome. Dan aspek yang berpengaruh paling dominan adalah aspek Social Influence atau Pengaruh Sosial.

\section{DaftarPustaka}

Bahrun, Suryadi., Alifah, Suryani., Mulyono, Sri., (2017), "Rancang Bangun Sistem Informasi Survey Pemasaran dan Penjualan Berbasis Web", Jurnal Transistor Elektro dan Informatika Vol. 2 No. 2, Semarang.

Burgess, R. G., (1982). "Field Research: a Sourcebook and Field Manual". London

Consumer Business Dashboard - MS2N, (2018), "Report Automation", http://mydashboard.telkom.co.id/m s2/, (diakses tanggal 3 Juni 2020)

Dinas Kominfo Kota Banjarbaru (Diskominfo) (2019), "Sejarah Kota Banjarbaru", https://www.banjarbarukota.go.id/s ejarah, (diakses tanggal 7 Agustus 2019)

Ghozali, Imam. (2013). “ Aplikasi Analisis Multivariate dengan Program IBM SPSS 21 Update PLS Regresi”. Semarang: Badan Penerbit Universitas Diponegoro

Indika, Deru R., Jovita, Cindy, (2017), "Media Sosial Instagram Sebagai Sarana Promosi untuk Meningkatkan Minat Beli Konsumen", Jurnal Bisnis Terapan ISSN 2580-4928, Bandung.

Indrawati, (2018), "Metode Penelitian Kualitatif: Manajemen dan Bisnis Konvergensi Teknologi Informasi dan Komunikasi”, PT Refika Aditama, Bandung

Kotler, Philip, (2005), "Manajemen Pemasaran Jilid 2", Edisi
Kesebelas, Indeks, Jakarta.

Lamb, C.W., Hair, J.F., and McDaniel, C.,(2007),"Essential of Marketing”, 5 th Edition, Cengage Learning, Ohio.

Manggolo, Inu., Marzuki, Marza Ihsan., Alaydrus, Mudrik., (2011), "Optimalisasi Perencanaan Jaringan Akses Serat Optik Fiber to the Home Menggunakan Algoritma Genetika", InComTech, Jurnal Telekomunikasi dan Komputer, vol. 2, no.2, 2011

Malkia, M., Anttiriko, A. V., Savolainen, R., (2004), "eTransformation in Governance - New Directions in Government and Politics", Idea Group Publishing, USA.

Masykur, F., Prasetiyowati, F., (2016), "Aplikasi Rumah Pintar (Smart Home) Pengendali Peralatan Elektronik Rumah Tangga Berbasis Web", Jurnal Sains Teknologi dan Industri Vol. 14, Ponorogo.

Neuman, W. L., (2003), "Social Research Methods, Qualitative and Quantitative Approaches". Fifth Edition. Boston: Pearson Education.

Nugroho, Kurnianto T., Kusrini, Sudarmawan, (2018), "Pengujian Sistem Informasi Pengelolaan Keuangan Daerah Berbasis WEB Kabupaten Majalengka dengan Menggunakan UTAUT 2", Prosiding Seminar Nasional Geotik 2018, ISSN : 2580 - 8796, Yogyakarta.

Nurdiani, Nina, (2014), "Teknik Sampling Snowball Dalam Penelitian Lapangan", Comtech Vol. 5 No. 2 Desember 2014 : 1110 - 1118, Jakarta.

Putranto, A. M., Pramudiana, Y., (2015), "Pengaruh Faktor-Faktor dalam Modifikasi Unified Theory of Acceptance and Use of Technology 2 terhadap Perilaku Konsumen dalam Mengadopsi Layanan Wifi PT. XYZ area Jakarta", eProceeding of Management: Vol. 2, No. 2 Agustus 2015, Halaman 1085 - 1093, ISSN : 2355-9357, Bandung.

Ramadhani, Graifhan, (2003), "Modul Pengenalan Internet", http://dhani.singcat.com, diakses tanggal 16 Oktober 2020

Rahardjo, Budi, (2001), “Aspek Teknologi dan Keamanan dalam Internet Banking", PT INDOCISC http://www.indocisc.com, diakses tanggal 22 Agustus 2020

Rosalina, V., Sugiyani, Y., Triayudi, A., 
(2014), "Perancangan Infrastruktur Jaringan Komputer dalam Konsep Membangun Serang Menuju Smart City", Jurnal PROSISKO, Serang.

Rosanto, F., Zulherman, D., Khair, F., (2017), "Analisis Perancangan Jaringan Fiber to the Home Area Jakarta Garden City dengan Metode Link Power Budget dan Rise Time Budget", $2^{\text {nd }}$ Seminar Nasional IPTEK Terapan 2017, Tegal.

Sarjono, H. dan Julianita, W. (2011). "SPSS vs LISREL: Sebuah Pengantar, Aplikasi untuk Riset”. Jakarta: Salemba Empat.

Setiadi, Nugroho J., (2013), “Perilaku Konsumen: Perspektif Kontemporer pada Motif, Tujuan, dan Keinginan Konsumen", Edisi Revisi, Kencana, Jakarta.

Siregar,(2010), "Perancangan Portal Berbasis Web dengan Menggunakan PHP dan MySQL pada SMA Negeri 18 Medan", Sumatera Utara.

Sugiyono, (2010). Statistika untuk Penelitian. Bandung: Alfabeta

Sugiyono, (2013). "Metode Penelitian Kuantitatif, Kualitatif, dan Kombinasi (Mixed Methods)". Bandung : Alfabeta.

Supangkat, Suhasono H., (2006), "Framework Strategi Implementasi E-Government", Multimedia and
Cyberspace Research Group Institut Teknologi Bandung, Bandung.

Venkatesh, V., Morris, M. G., Davis, G. B., and Davis, F. D., (2003), "User Acceptance of Information Technology: Toward a Unified View", MIS Quarterly. September. Vol. 27. No. 3. H. 425-478, USA.

Venkatesh, V., Thong, J.Y.L. and Xu, X., (2012), "Consumer Acceptance and Use of Information Technology: Extending the Unified Theory of Acceptance and Use of Technology", MIS Quarterly, Vol. 36, pp. 157-178, USA.

Walikota Banjarbaru, (2016), "Peraturan Walikota Banjarbaru Nomor 96 Tahun 2016", http://ble.diskominfotik.Banjarbaru kota.go.id/2017/01/dasar-

hukum.html, (diakses tanggal 18 Desember 2017)

Widoyoko, E. P. (2012). "Teknik Penyusunan Instrumen Penelitian. Yogyakarta: Pustaka Pelajar.

Wigati, Sri., (2011), "Perilaku Konsumen dalam Perspektif Ekonomi Islam", Fakultas Syariah IAIN Sunan Ampel Surabaya Vol. 01, No. 01, Juni 2011

Yurmama, Tri F., Azman, N., (2009), "Perancangan Software Aplikasi Pervasive Smart Home", Seminar Nasional Aplikasi Teknologi Informasi 2009, Yogyakarta. 